Article

\title{
Cost and Scenario Analysis of Intermodal Transportation Routes from Korea to the USA: After the Panama Canal Expansion
}

\author{
Junseung Kim ${ }^{1}$, Kyungku Kim ${ }^{2}$, Kum Fai Yuen ${ }^{3}{ }^{10}$ and Keun-Sik Park ${ }^{4, *}$ \\ 1 Department of International Trade and Logistics, Graduate School, Chung-Ang University, 84 Heukseok-ro, \\ Dongjak-gu, Seoul 06974, Korea; 311jsk@hanmail.net \\ 2 Department of Shipping and Logistics, Graduate School of Human Resources Development, Chung-Ang \\ University, 84 Heukseok-ro, Dongjak-gu, Seoul 06974, Korea; whisker3k@hotmail.com \\ 3 School of Civil and Environmental Engineering, Nanyang Technological University, Singapore 639798, \\ Singapore; kumfai.yuen@ntu.edu.sg \\ 4 Department of International Logistics, College of Business and Economics, Chung-Ang University, \\ 84 Heukseok-ro, Dongjak-gu, Seoul 06974, Korea \\ * Correspondence: pksik0371@cau.ac.kr; Tel.: +82-02-820-5798
}

Received: 18 June 2020; Accepted: 4 August 2020; Published: 6 August 2020

\begin{abstract}
This study is aimed at suggesting the most economical transportation route by comparing seven different Korea-US intermodal transportation routes for automotive parts exported to Southeastern USA. To keep up with the global competition of parts makers, which are expanding their markets based on advanced technology and enormous capital, Korean automotive parts makers also need to actively advance their markets overseas. From this point of view, selecting an efficient transport route and transportation modes for overseas export is essential. To this end, the most efficient transportation route from the perspective of total logistics cost was selected by adapting the inventory-theoretic model, using information such as the logistics status of a specific company and the logistics freight rates and transit time for the third quarter of 2019. Thus, the scenario analysis was conducted assuming that variables-namely transportation cost per unit, commodity value, inventory cost and additional conditions such as terminal free time-were modified. Through this study, the optimal transportation route was selected by fully considering and predicting the total logistics cost component and the variability of the major factors.
\end{abstract}

Keywords: intermodal transportation; route selection; inventory-theoretic model; scenario analysis; terminal free time; Panama Canal

\section{Introduction}

Today, with the globalization of the economy and the development of communication and logistics technology, world trade is changing rapidly. In addition, exports from Korea to the USA are increasing [1]. As the company's management activities are globalized, the supply chain is not only expanding worldwide but also reducing inventory because of the just-in-time (JIT) production system. Therefore, the establishment of a global logistics system and efficient supply chain management are important strategies for the company's survival. Meanwhile, the supply chain is expanding globally due to the fierce competition in auto industry, cost and production lead time reduction and critical deadline [2].

Around 25,000 parts are needed to produce a finished car; the accuracy and timeliness of procurement logistics and the efficiency of the entire logistics process are important factors in corporate competitiveness. In particular, Hyundai and Kia Motors are currently operating 13 factories in nine 
overseas countries; hence, the importance of global procurement logistics for automotive parts is increasingly emphasized as the overseas production of finished cars increases. Furthermore, automotive parts are ranked fifth among Korean exports [3]. Local procurement of automotive parts may be promoted in the long term, but procurement of automotive parts in Korea will be inevitable if their quality and cost competitiveness are premised.

As Korean automotive parts companies still lack expertise in related fields in international logistics to advance into the overseas market, an optimized logistics operation is essential to secure long-term growth competitiveness in a fierce global competitive market such as the USA. The long lead time, high transportation cost, delay in delivery and risk of accidents during long-distance transportation have been a significant burden to shippers; thus, considering various factors during transport, it is essential to select an efficient transportation route and mode.

Existing research related to transportation route selection can be divided into a selection factor approach, using mixed-integer programming and dynamic programming, and a real data approach [4]. The transportation cost and transit time, which are important factors in the selection factor approach [5,6], were reflected in this research. In recent research, mathematical algorithms like mixed-integer programming and dynamic programming were used [7-13]. However, these studies mainly stress particular routes or industries $[14,15]$, and giving significant suggestions to each company is occasionally difficult [4]. Most real data approaches were conducted through economic model analysis [16-21], and the total logistics cost was calculated, which explained that the most economical transportation route is the optimal transportation route. Thus, after the Panama Canal expansion, this research uses real freight rate, transit time and various route services currently formed in the shipping market. In the existing studies, the in-transit inventory cost was included, but little research has adopted air transport that is important in automotive parts logistics, which is often used to meet delivery times. Therefore, building upon the existing literature, this paper investigates the impact of air transportation and each route's port additional conditions on costs in order to check the volatility of the total logistics cost through the scenario analysis of major variables and ensure accuracy in the optimal transportation route selection. Therefore, this study suggests the most efficient transportation route by comparing the transportation route and mode of the Korean automotive parts exporter. In addition, by supplying automotive parts through the most efficient transportation routes, local manufacturing plants in the US enable sustainable production.

The remainder of this paper is structured as follows. Section 2 reviews route selection and US logistics, Section 3 presents the research assumptions and models and Section 4 presents the optimal transportation route by comparing the total logistics cost between transportation routes. Section 5 presents the scenario analysis, which was conducted assuming changes in freight rates, inventory cost and commodity value. Moreover, Section 6 applies the free time to help the shipper in selecting the optimal transportation mode in response to the rapidly changing logistics market flow. Lastly, Section 7 suggests the implications, summary and future research.

\section{Literature Review}

Existing research related to transportation route selection can be divided into three major sections: the real data approach, using mathematical algorithms, e.g., mixed-integer programming and dynamic programming, and the selection factor approach. The real data approach is a method of studying the factors that affect the selection of mode of transportation and their effects through the analysis of the resulting figures, such as import and export items, time of departure for transportation and cargo value. Mathematical algorithms are mainly used to derive the optimal solution, such as minimum cost in a specific mode or route. The selection factor approach is a method of evaluating each factor by selecting factors that are expected to affect the shipper's transportation route in advance and deriving values for each factor. 


\subsection{Route Selection}

There are several factors to consider when selecting a transportation route and mode, but existing studies have mainly selected transportation cost and transportation time as the most essential factors. Collison [22] categorized ocean carriers' service attributes into the timeliness of service, facilities and equipment, traffic services, pricing and rates and marketing services. Meanwhile, Mcginnis [23] classified freight transportation decision factors into transportation and non-transportation costs, such as reliability, transit time, over, short and damaged, shipper market considerations, carrier considerations and product characteristics, and analyzed their importance. The results of the study show that transit time was more important than freight rates. Recent studies used multiple-criteria decision analysis $[5,14,15]$. Moon et al. [5] gave the highest weight to transport cost and transport time. Pham and Yeo [15] adopted the Delphi Method and consistent fuzzy preference relations to analyze electronic components transportation route selection factors from Shenzen, China, to Hiapong, Vietnam; they determined that reliability and transportation costs were important factors. Meanwhile, Wang and Yeo [14] ranked total cost as an important factor. Kim et al. [24] analyzed the factors that Korean logistics companies take into account to adopt the Trans-Siberian Railway (TSR) in the Russian Far East; reduction of transportation distance and time were most crucial.

Another group is using mathematical algorithms, e.g., mixed-integer programming and dynamic programming. Some studies concentrate on a particular mode or route by employing mixed-integer programming [7-11]. To handle the uncertain environment of the multimodal freight transportation problem, the generalized interval fuzzy mixed-integer programming model was presented by Tian and Cao [12]. Hao and Yue [13] presented an optimization model based on dynamic programming to suggest the best modes of transportation for a container multimodal transport. However, these studies mainly stress particular routes or industries [14,15], and giving significant suggestions to each company is occasionally difficult [4].

The other group is the real data approach, which is mainly conducted through economic model analysis, calculating the total logistics cost. The transportation route with the lowest cost becomes the optimal transportation route. The transport route selection model was sorted into the classic economic model, the inventory-theoretic model, the trade-off model and the constrained optimization model proposed by McGinnis [23]. Cunningham [25] itemized the traditional approach and revealed a preference approach, behavioral models and inventory-theoretic model. Some studies based on real data compared routes using the Beresford cost-distance model [16-21]. Regmi and Hanaoka [21] applied the time-cost-distance approach to analyze the route connecting Northeast Asia and Central Asia. In addition, the confidence index was covered by the cost model $[17,19,20]$. Seo et al. [19] added a confidence index to the Beresford cost model to select the laptop export route from Chongqing, China, to Rotterdam, Holland. The multimodal transportation using the inland waterway from Chongqing to Shanghai and sea transportation to Rotterdam had the lowest cost, and the rail transportation via Urumchi, except for air transportation, had the shortest transit time. However, this model is based on simplified assumptions, using cost distance and time distance as variables [4]. Meanwhile, Liu and Kronbak [26] compared the economic feasibility of the Northern Sea route (NSR) with the route via Suez Canal (SC) based on economic factors, excluding navigational, environmental and legal factors. The factors that have the greatest effect on the economic efficiency of the NSR are the toll, travel time and fuel price. Shibasaki et al. [27] applied an aggregated logit model to compare the dry bulk carriers' route among SC, Panama Canal and Cape of Good Hope, based on the vessel movement database. Wang et al. [28] proposed a connectivity reliability-cost approach to select the crude oil maritime transportation path and carried out a case study using real data concerning China's maritime transportation network. Moreover, Verny and Grigentin [29] calculated the transportation cost per twenty-foot equivalent (TEU) required for container cargo transportation between Hamburg and Shanghai. They analyzed the cost by dividing the routes into five: the existing Asia-Europe route using the SC, NSR, TSR, sea and air and air transportation. Zeng et al. [30] analyzed the competitiveness of NSR, the SC route and railway in Northeast China, East China and South China shipping regions 
under the impact of the belt and road initiative. The result showed that appeal is limited but NSR commercialization was most captivating in the northeast area. Previous studies on the real data approach have been conducted in comparative analyses of export routes to Russia and Europe, which is seemingly due to the distinct characteristics of TSR and maritime transportation modes.

\subsection{Overview of US Logistics}

Intermodal transportation from Korea to the USA is categorized into mini land-bridge, micro land-bridge (MLB), all water (A/W) via the Panama Canal and reverse interior point intermodal (RIPI). The MLB was invented to solve the problem of the mini land-bridge, a shortcoming of the port-to-port transport with poor practicality for shippers located in the interior of the USA. A/W is a port-to-port transport route through the Panama Canal. RIPI is an intermodal transportation route by sea via the Panama Canal to the US East Coast and uses railroads and trucks to transport inland. Basically, since RIPI is transportation provided by adding the A/W service via the Panama Canal and inland transportation service, this paper classifies A/W and RIPI as similar concepts. Moreover, $\mathrm{A} / \mathrm{W}$ and MLB routes are more efficient for transportation from Northeast Asia [31]; the routes via SC and Cape Horn were excluded in this study. Figure 1 shows the basic concept of the MLB route and A/W route.

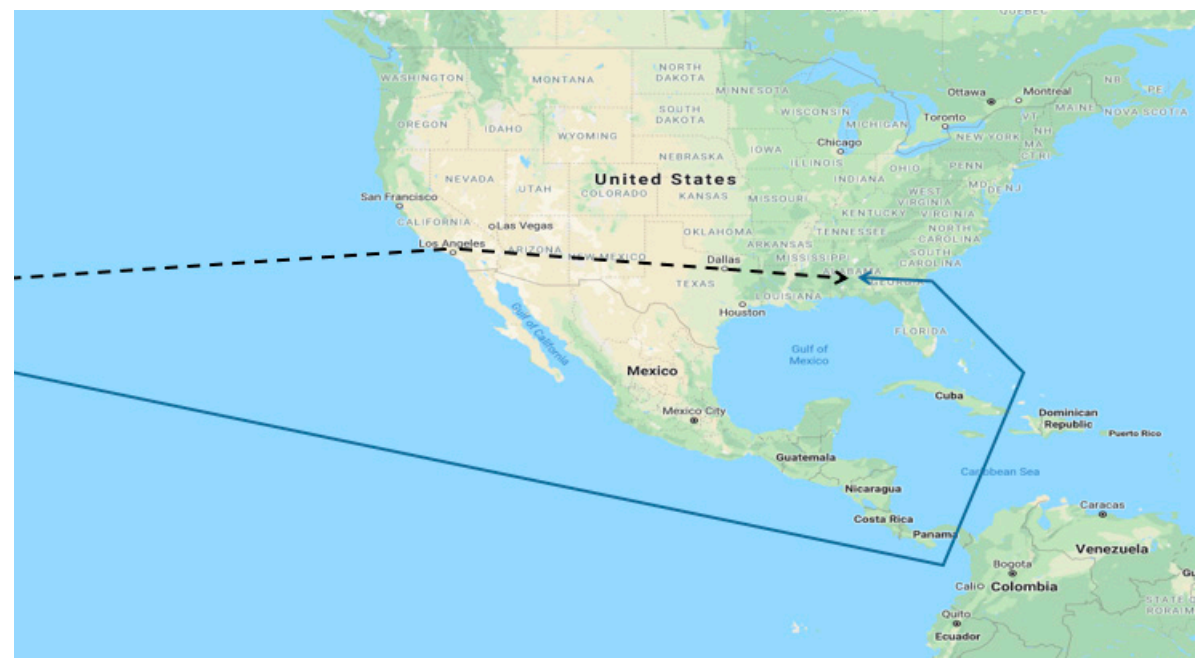

Figure 1. Intermodal Routes from Korea to USA. - - - - - - - MLB route; $\mathrm{A} / \mathrm{W}$ route through

Panama Canal.

Woo et al. [4] applied the inventory-theoretic model based on real data from 2013 to 2014 to select the optimal route using MLB and A/W maritime transportation from Korea to Luverne, USA. Several studies have analyzed the effects of the Panama Canal Expansion [31-36]. In particular, Salin [31] analyzed the effect of the Panama Canal expansion on the transportation route by comparing the route through the SC, the route via the Panama Canal and the US Intermodal System with transit time. Meanwhile, Martinez et al. [32] investigated the influence of the Panama Canal expansion on the selection of the East Coast port that uses the US Intermodal System and the West Coast port through the Panama Canal by utilizing a binomial logit model composed of freight ratio, transit time, commodity type and value per metric ton from Asia to Pittsburgh based on data from the Port Import Export Reporting Service (PIERS) and the Census Bureau's International Merchandise Trade publication. However, this present study uses estimated values of fare and transit time and assumes that only the canal transit time changes when the canal is expanded. Ungo and Sabonge [33] developed the Panama Canal Route Competitive Analysis Model (PCRCAM), and the competitiveness of the Panama Canal was measured by comparing the transportation cost and competitive index of the route by way of the Panama Canal, the route through the Cape Horn and the US Intermodal System. In addition, the contradiction case scenario and the growth case scenario were set to check fluctuation. 
Van Hassel et al. [34] explored the effect of the expanded Panama Canal on future cargo flow change, and Moryadee and Gabriel [35] analyzed the how the Panama Canal's capacity level of liquefied natural gas (LNG) tanker affects the global gas market and the export of LNG from the Gulf of Mexico. Liu et al. [36] used cooperative game theory to examine the influence of the Panama Canal expansion on competitive-cooperative connections with the US container import market and allocation of market dominance among transportation service providers from Hong Kong to Norfolk. With the expansion of the Panama Canal, the East Coast port has had a positive impact and is said to give East Coast route (ECR) players a competitive advantage. In addition, shipping companies preferred ECR when using the same ship. Other studies examined changes in environmental impacts related to the expansion of the Panama Canal [37-39]. Corbett et al. [37] applied the geospatial intermodal freight transportation (GIFT) model to figure out changes in $\mathrm{CO}_{2}$ and non- $\mathrm{CO}_{2}$ emissions in the route from Asia to the USA as a result of the Panama Canal expansion. De Marucci [38] divided the scenario into existing canals and expanded canals and compared $\mathrm{CO}_{2}$ emissions by considering physical distances, closest alternative routes, vessels fuel consumption and other relevant transportation modes. Meanwhile, Pham et al. [6] chose the transportation route selection factors from Hong Kong to New York after the expansion of the Panama Canal and compared the selection factors and alternative routes using Fuzzy Technique for Order of Preference by Similarity to Ideal Solution (TOPSIS); they determined the A/W route to be the most preferred route. Prior studies on US logistics have focused on comparative analyses of MLB and $\mathrm{A} / \mathrm{W}$ routes, and most of them forecasted and analyzed the effect of the Panama Canal expansion. Results of the literature review revealed that most of the real data approaches were conducted through economic model analysis, and the total logistics cost was calculated, which explained that the most economical transportation route is the optimal transportation route. In addition, the transportation cost and transit time, which are important factors in the selection factor approach, were reflected in this research. Thus, to conduct realistic research after the Panama Canal expansion, the present study uses real freight rate, transit time and various route services currently formed in the shipping market during the third quarter of 2019. In the existing studies, the inventory cost was rarely included; also, little research analyzed air transport, which is essential in automotive parts logistics often used to meet delivery times. Therefore, building upon the existing literature, this paper investigates the impact of the air transportation and each route's port's additional conditions on costs to check the volatility of the total logistics cost through the scenario analysis of major variables and to ensure accuracy in the optimal transportation route selection.

\section{Research Methods and Data Collection}

For export transportation to Alabama (AL), in the southeastern region of the USA, the total logistics costs were calculated, and the transportation route with the minimum logistics cost was selected by comparing the competing transportation route, transit time, transport cost and inventory cost. The basic assumptions of selecting the transport route for the research model analysis are shown in Table 1.

The final destination is Montgomery, AL, where company A's US manufacturing plants and warehouses are located. Busan port is the departure point and the export condition is delivered at place (DAP). All transport modes use a $40^{\prime} \mathrm{HC}$ standard container, and the freights are automotive parts. Annual commodity demand is 50 units per week shipped for 52 weeks, total 2600 units annually. HMM and ONE Line were used for the service via the West Coast, whereas MAERSK and ZIM LINE were used for the service via the East Coast. Local rail transportation is provided by the OC intermodal transport service, and truck transportation is carried out separately by a logistics company in the USA. Air transport service was provided by Korean Air. Sea and air fares were based on average freight all kind (FAK) fares in the third quarter of 2019, which is after the Panama Canal expansion, whereas truck fares were based on average freight out of three US truckers. The free time provided by OCs, ports and railroad ramps was not exceeded, and no additional demurrage and detention costs were incurred. Insurance on goods and customs clearance costs were excluded from logistics costs because 
these are the same expenses that occur regardless of the transport mode. The ordering cost was also assumed to be included in the transport cost as its amount was insignificant. Safety stock at a US warehouse is four weeks and the commodity value is USD 50,000.

Table 1. Research assumptions.

\begin{tabular}{|c|c|c|}
\hline No. & Contents & Notes \\
\hline 1 & $\begin{array}{l}\text { Transport section: Korea-Montgomery, AL, US, company A's } \\
\text { manufacturing plant warehouse }\end{array}$ & \\
\hline 2 & $\begin{array}{l}\text { Cargo origin: Busan Port, Incheon Airport } \\
\text { Export condition: Delivered At Place (DAP), Montgomery, AL }\end{array}$ & \\
\hline 3 & $\begin{array}{l}\text { Shipping container: } 40^{\prime} \mathrm{HC} \text { standard container (FEU) } \\
\text { Commodity type: automotive parts } \\
\text { Annual commodity demand: } 2600 \text { units ( } 50 \text { units/week) }\end{array}$ & $\begin{array}{c}\text { One } 40^{\prime} \mathrm{HC} \\
\text { Weight: } 5000 \mathrm{~kg} \\
\text { CBM: } 23.664\end{array}$ \\
\hline 4 & $\begin{array}{l}\text { MLB Ocean Carrier (OC): Hyundai Merchant Marine (HMM), } \\
\text { Ocean Network Express (ONE) } \\
\text { A/W OC: Maersk, ZIM Line } \\
\text { Local trucking company: GFA, SHORELINE, GET } \\
\text { Airline: Korean Air }\end{array}$ & $\begin{array}{l}\text { Rail Transportation } \\
\text { Provided by OC }\end{array}$ \\
\hline 5 & Sea/air/inland fares: based on freight all kind (FAK) of 3Q 2019 & \\
\hline 6 & $\begin{array}{l}\text { Does not exceed OCs and terminals' free time } \\
\text { No demurrage, detention or over-storage cost }\end{array}$ & \\
\hline 7 & $\begin{array}{l}\text { Exclude insurance costs and customs clearance costs such as } \\
\text { insurance on goods and international cargo liability } \\
\text { Ordering cost: assumed included in transportation cost } \\
\text { Inventory cost per unit: } 10 \% \text { of commodity price and } 10 \% \\
\text { interest rate on annual shipment value }\end{array}$ & \\
\hline 8 & Local safety stock: 4 weeks & \\
\hline 9 & Commodity price: $\$ 50,000 / 40^{\prime} \mathrm{HC}$ & \\
\hline
\end{tabular}

\subsection{Research Methods}

According to Baumol and Vinod's [40] model of transportation mode selection, the selection of transportation mode is determined in terms of minimizing the overall logistics costs. The total logistics cost is the sum of direct shipping, in-transit carrying, ordering and warehouse inventory costs. The formula is as follows:

$$
\mathrm{TC}=\mathrm{rD}+\mathrm{ItDC}+\mathrm{S}(\mathrm{D} / \mathrm{Q})+\mathrm{IC}(\mathrm{Q} / 2)
$$

TC: Total logistics costs combined with inventory and transport costs

$\mathrm{R}$ : Transportation cost per unit from origin to destination

D: Annual demand of goods

I: Inventory cost per unit (percentage of commodity price and interest rate on annual shipment value)

T: Transit time (proportion of 365 days)

C: Commodity value

S: Cost per order

Q: Quantity (per shipment).

In the above formula, the following conditions are met:

1. The direct shipping cost is as follows:

$$
r \times D
$$


2. In-transit carrying cost consists of the following:

$$
I \times t \times D \times C
$$

3. Ordering cost is expressed as the following:

$$
S \times(D / Q)
$$

4. Warehouse inventory costs consist of the following:

$$
I \times C \times(Q / 2)
$$

where $Q / 2$ is the average inventory calculated as half of a single shipment.

Since the warehouse inventory costs of the basic Function (1) are inventory for ordinary sales, the inventory cost has to be modified due to the characteristics of the automotive parts industry operating with securing the safety stock for 4 weeks or more. In the case of the finished car production line, when production is disrupted due to delayed parts supply, a huge amount of claims costs is charged per hour or even per minute. Hence, it is realistically corrected considering this special situation. Inventory cost is based on average inventory level (AIL), defined as follows:

$$
A I L=A T+(A S-S S)+S S
$$

\section{AT: Average transition \\ AS: Average stock \\ SS: Safety stock}

where average transition is the average of stock in-transit, the difference between average stock and safety stock is the stock for normal sale and safety stock is the preparation for demand and lead time uncertainty. This equation is also expressed as the following:

$$
\mathrm{O} \times \operatorname{ASLT} \times(\mathrm{No} / 365)+(\mathrm{O} / 2)+\mathrm{SR} \times \mathrm{dT}
$$

\section{O: Order quantity}

ASLT: Average shipping lead time

No: Number of order per year

SR: Service rate

dT: Deviation in demand during the transport

where the deviation in demand during the transport follows the change in transit time and demand.

In Equation (6), the $\{\mathrm{AS}-\mathrm{SS}\}$ is expressed as $Q / 2$, which is half of the order volume. Meanwhile, safety stock is expressed as $4 Q$, and 4 weeks reflect the aforementioned characteristics of automotive parts procurement logistics. Therefore, the modified function is as follows:

$$
T C=r D+I t D C+S(D / Q)+I C(Q / 2+4 Q)
$$

\subsection{Data Collection}

Company A, a finished car manufacturer in Montgomery, AL, in the southeastern region of the USA, determines transportation routes and modes by considering several factors, such as transport cost and transit times in the US transportation market. Table 2 lists all transportation routes and modes currently transporting to Montgomery. 
Table 2. Transportation cost and transit time to Montgomery, USA.

\begin{tabular}{|c|c|c|c|c|c|c|c|c|c|c|c|}
\hline \multirow{2}{*}{ No. } & & \multirow{2}{*}{ Modes } & \multirow{2}{*}{$\begin{array}{c}\text { Port of } \\
\text { Shipment }\end{array}$} & \multirow{2}{*}{$\begin{array}{l}\text { Port of } \\
\text { Arrival }\end{array}$} & \multirow{2}{*}{ Rail } & \multicolumn{3}{|c|}{ Transport Cost (FEU) } & \multicolumn{3}{|c|}{ Transit Time (Day) } \\
\hline & & & & & & Sea/Air & Rail & Truck & Sea/Air & $\begin{array}{l}\text { Load and } \\
\text { Unload/Rail }\end{array}$ & $\begin{array}{c}\text { Load and } \\
\text { Unload/Truck }\end{array}$ \\
\hline 1 & \multirow{3}{*}{ MLB } & $\begin{array}{c}\text { Truck } \\
\text { (Team) }\end{array}$ & Busan & LA & - & $\$ 1500$ & - & $\$ 6500$ & 11 & - & 3 \\
\hline 2 & & $\begin{array}{c}\text { Truck } \\
\text { (Single) }\end{array}$ & Busan & LA & - & $\$ 1500$ & - & $\$ 6100$ & 11 & - & 5 \\
\hline 3 & & Rail + Truck & Busan & LA & Atlanta & $\$ 1500$ & $\$ 2010$ & $\$ 655$ & 11 & 8 & 1 \\
\hline 4 & \multirow{3}{*}{$\mathrm{A} / \mathrm{W}$} & Truck & Busan & Mobile & - & $\$ 2875$ & - & $\$ 685$ & 28 & - & 2 \\
\hline 5 & & Truck & Busan & Savannah & - & $\$ 2625$ & - & $\$ 1085$ & 23 & - & 2 \\
\hline 6 & & Rail + Truck & Busan & Savannah & Atlanta & $\$ 2625$ & $\$ 505$ & $\$ 685$ & 23 & 2 & 1 \\
\hline 7 & Air & Air + Truck & Incheon & Atlanta & - & $\$ 19,500$ & - & $\$ 950$ & 1 & - & 1 \\
\hline
\end{tabular}

Notes: Sea/Rail fare: Major OCs' average FAK fare in 3rd quarter of 2019. Air fare: Korean airlines' average FAK fare in 3rd quarter of 2019. Truck fare: average freight out of 3 truckers in the USA in 3rd quarter of 2019.

\section{Cost Analysis}

In Sections 4 and 5, the optimal transportation routes between Korea and the USA are selected by analyzing total logistics cost and scenario analysis reflecting inventory costs. In cost analysis, the total logistics cost formula is classified into each cost item and compared. In this case, the ordering cost is not separately analyzed as it is regarded as being included in the direct shipping costs.

\subsection{Direct Shipping Costs}

The direct shipping cost is calculated as in Formula (2). In this study, the basic unit of transportation is $40^{\prime} \mathrm{HC}$, and 50 parts were assumed to be shipped every week for 52 weeks. Table 3 shows the direct shipping costs of the seven routes and values of variables.

Table 3. Direct shipping cost variables.

\begin{tabular}{|c|c|c|c|c|c|}
\hline \multirow{2}{*}{ No. } & & \multirow{2}{*}{ Modes } & \multicolumn{2}{|c|}{ Variables } & \multirow{2}{*}{$\begin{array}{c}\text { Direct Shipping } \\
\text { Cost (rD) }\end{array}$} \\
\hline & & & $\mathbf{r}$ & $\mathbf{D}$ & \\
\hline 1 & \multirow{3}{*}{ MLB } & Truck (Team) & $\$ 8000$ & 2600 & $\$ 20,800,000$ \\
\hline 2 & & Truck (Single) & $\$ 7600$ & 2600 & $\$ 19,760,000$ \\
\hline 3 & & Rail + Truck & $\$ 4165$ & 2600 & $\$ 10,829,000$ \\
\hline 4 & \multirow{3}{*}{$\mathrm{A} / \mathrm{W}$} & Truck (via Mobile) & $\$ 3560$ & 2600 & $\$ 9,256,000$ \\
\hline 5 & & Truck (via Savannah & $\$ 3710$ & 2600 & $\$ 9,646,000$ \\
\hline 6 & & Rail + Truck & $\$ 3815$ & 2600 & $\$ 9,919,000$ \\
\hline 7 & Air & Air + Truck & $\$ 20,450$ & 2600 & $\$ 53,170,000$ \\
\hline
\end{tabular}

\subsection{In-Transit Carrying Costs}

The in-transit carrying costs consist of the inventory cost per unit (I), transit time $(t)$, annual demand of goods (D) and commodity value (C). The inventory cost (I) per unit is assumed to be 0.1 of the commodity value and 0.1 interest rate on annual shipment value. In the case of the automotive parts industry, the identical products are supplied continuously for several years, and as it is guaranteed to be injected into the finished car production line, the risk of unused inventory is considerably low. However, interest expenses are incurred due to delayed cashing of inventory. Thus, inventory cost per unit (I) is set as 0.2 . The transit time ( $\mathrm{t}$ ) is calculated by dividing the total transit time by 365 days. Moreover, the annual demand for goods is consistent for 50 units per week, and the commodity value is assumed as $\$ 50,000$. Table 4 is a summary of in-transit carrying costs. 
Table 4. In-transit carrying cost variables.

\begin{tabular}{|c|c|c|c|c|c|c|c|}
\hline \multirow{2}{*}{ No. } & & \multirow{2}{*}{ Modes } & \multicolumn{4}{|c|}{ Variables } & \multirow{2}{*}{$\begin{array}{c}\text { In-Transit } \\
\text { Carrying Cost } \\
\text { (ItDC) }\end{array}$} \\
\hline & & & $\mathbf{I}$ & $\mathbf{t}$ & D & $\mathrm{C}$ & \\
\hline 1 & & Truck (Team) & 0.2 & $14 / 365$ & 2600 & $\$ 50,000$ & $\$ 997,260$ \\
\hline 2 & MLB & Truck (Single) & 0.2 & $16 / 365$ & 2600 & $\$ 50,000$ & $\$ 1,139,726$ \\
\hline 3 & & Rail + Truck & 0.2 & $20 / 365$ & 2600 & $\$ 50,000$ & $\$ 1,424,658$ \\
\hline 4 & & Truck (via Mobile) & 0.2 & $30 / 365$ & 2600 & $\$ 50,000$ & $\$ 2,136,986$ \\
\hline 5 & $\mathrm{~A} / \mathrm{W}$ & Truck (via Savannah) & 0.2 & $25 / 365$ & 2600 & $\$ 50,000$ & $\$ 1,780,822$ \\
\hline 6 & & Rail + Truck & 0.2 & $26 / 365$ & 2600 & $\$ 50,000$ & $\$ 1,852,055$ \\
\hline 7 & Air & Air + Truck & 0.2 & $2 / 365$ & 2600 & $\$ 50,000$ & $\$ 142,466$ \\
\hline
\end{tabular}

\subsection{Warehouse Inventory Costs}

The warehouse inventory cost is obtained as follows:

$$
\mathrm{I} \times \mathrm{C} \times\{\mathrm{Q} \times(0.5+4)\}
$$

This represents the same value in all seven transport routes. Table 5 lists the values of variables on seven routes and warehouse inventory costs.

Table 5. Warehouse inventory cost variables.

\begin{tabular}{|c|c|c|c|c|c|c|c|}
\hline \multirow{2}{*}{ No. } & & \multirow{2}{*}{ Modes } & \multicolumn{4}{|c|}{ Variables } & \multirow{2}{*}{$\begin{array}{c}\text { Warehouse } \\
\text { Inventory Cost } \\
(\mathrm{IC}(Q * 4.5))\end{array}$} \\
\hline & & & $\mathbf{I}$ & $\mathrm{C}$ & $\mathrm{Q} \times 1 / 2$ & $\mathrm{Q} \times 4$ & \\
\hline 1 & & Truck (Team) & 0.2 & $\$ 50,000$ & 25 & 200 & $\$ 2,250,000$ \\
\hline 2 & MLB & Truck (Single) & 0.2 & $\$ 50,000$ & 25 & 200 & $\$ 2,250,000$ \\
\hline 3 & & Rail + Truck & 0.2 & $\$ 50,000$ & 25 & 200 & $\$ 2,250,000$ \\
\hline 4 & & Truck (via Mobile) & 0.2 & $\$ 50,000$ & 25 & 200 & $\$ 2,250,000$ \\
\hline 5 & $\mathrm{~A} / \mathrm{W}$ & Truck (via Savannah) & 0.2 & $\$ 50,000$ & 25 & 200 & $\$ 2,250,000$ \\
\hline 6 & & Rail + Truck & 0.2 & $\$ 50,000$ & 25 & 200 & $\$ 2,250,000$ \\
\hline 7 & Air & Air + Truck & 0.2 & $\$ 50,000$ & 25 & 200 & $\$ 2,250,000$ \\
\hline
\end{tabular}

\subsection{Total Logistics Costs}

The result of total logistics cost was derived from Function (8), calculating the direct shipping costs, in-transit carrying costs and warehouse inventory costs for each of the seven transportation routes. Table 6 lists the value of total logistics costs on seven routes and shows the values of used variables.

Table 6. Total logistics costs by transportation mode.

\begin{tabular}{|c|c|c|c|c|c|c|c|c|c|}
\hline \multirow{2}{*}{ No. } & & \multirow{2}{*}{ Modes } & \multicolumn{6}{|c|}{ Variables } & \multirow{2}{*}{$\begin{array}{l}\text { Total Logistics } \\
\text { Cost (TC) }\end{array}$} \\
\hline & & & $\mathbf{r}$ & $\mathrm{C}$ & I & $\mathbf{t}$ & $\mathbf{D}$ & $\mathbf{Q}$ & \\
\hline 1 & \multirow{3}{*}{ MLB } & Truck (Team) & $\$ 8000$ & $\$ 50,000$ & 0.2 & $14 / 365$ & 2600 & 50 & $\$ 24,047,260$ \\
\hline 2 & & Truck (Single) & $\$ 7600$ & $\$ 50,000$ & 0.2 & $16 / 365$ & 2600 & 50 & $\$ 23,149,726$ \\
\hline 3 & & Rail + Truck & $\$ 4165$ & $\$ 50,000$ & 0.2 & $20 / 365$ & 2600 & 50 & $\$ 14,503,658$ \\
\hline 4 & \multirow{3}{*}{$\mathrm{A} / \mathrm{W}$} & Truck (via Mobile) & $\$ 3560$ & $\$ 50,000$ & 0.2 & $30 / 365$ & 2600 & 50 & $\$ 13,642,986$ \\
\hline 5 & & Truck (via Savannah) & $\$ 3710$ & $\$ 50,000$ & 0.2 & $25 / 365$ & 2600 & 50 & $\$ 13,676,822$ \\
\hline 6 & & Rail + Truck & $\$ 3815$ & $\$ 50,000$ & 0.2 & $26 / 365$ & 2600 & 50 & $\$ 14,021,055$ \\
\hline 7 & Air & Air + Truck & $\$ 20,450$ & $\$ 50,000$ & 0.2 & $2 / 365$ & 2600 & 50 & $\$ 55,562,466$ \\
\hline
\end{tabular}

Under the aforementioned assumptions, the most competitive transportation route was truck transportation via Mobile port on the maritime A/W route. For air and truck transportation via the 
LA port, the total logistics cost is remarkably high, making it difficult to be a suitable transportation mode for company A, which regularly transports large quantities of cargo. However, due to the characteristics of automotive parts logistics of handling a large number of items, urgent transportation due to shortage and defects of some parts is inevitable. Even though the transit time for team truck and single truck via LA differs only by two days, many urgent shippers do not hesitate to bear extra logistics costs, which are around 3.8\%, to reach their destinations immediately.

In the case of the MLB rail transportation mode, the logistics cost is around $6.3 \%$ higher than the truck transportation via the Mobile port and around 6\% higher than the truck transportation via the Savannah port. In the past, the size of A/W route service vessels on the Northeast Asia-US East Coast route was 5000 TEU, but the expansion of the Panama Canal in 2016 allowed 14,000 TEU ships to pass through the canal. Accordingly, the supply on the A/W line increased [41,42]; therefore, it was possible to secure a fare competitiveness compared to MLB. Additionally, West Coast ports such as LA and Long Beach are congested [32], which often causes delays in rail connections. As a result of this delay, even shippers who place emphasis on transit time tend to show a preference for $\mathrm{A} / \mathrm{W}$ services that have better punctuality even if they take longer.

As shown in Table 7, the items that account for the highest proportion of total logistics costs are direct shipping costs, which comprise more than $67 \%$ among all seven transport modes. The in-transit carrying cost for the $\mathrm{A} / \mathrm{W}$ transportation mode via the Mobile port, which takes the longest transit time, is $16.5 \%$. In order to lower the total logistics cost, minimizing direct shipping costs is the most important method.

Table 7. Composition of total logistics cost by transportation mode.

\begin{tabular}{|c|c|c|c|c|c|c|c|c|c|}
\hline No. & & Modes & $\begin{array}{c}\text { Direct } \\
\text { Shipping } \\
\text { Cost }\end{array}$ & $\begin{array}{c}\text { Percent } \\
\text { (\%) }\end{array}$ & $\begin{array}{l}\text { In-Transit } \\
\text { Carrying } \\
\text { Cost }\end{array}$ & $\begin{array}{l}\text { Percent } \\
(\%)\end{array}$ & $\begin{array}{l}\text { Warehouse } \\
\text { Inventory } \\
\text { Cost }\end{array}$ & $\begin{array}{c}\text { Percent } \\
(\%)\end{array}$ & $\begin{array}{c}\text { Total } \\
\text { Logistics } \\
\text { Cost (TC) }\end{array}$ \\
\hline 1 & \multirow{3}{*}{ MLB } & $\begin{array}{l}\text { Truck } \\
\text { (Team) }\end{array}$ & $\$ 20,800,000$ & 86.5 & $\$ 997,260$ & 4.1 & $\$ 2,250,000$ & 9.4 & $\$ 24,047,260$ \\
\hline 2 & & $\begin{array}{l}\text { Truck } \\
\text { (Single) }\end{array}$ & $\$ 19,760,000$ & 85.4 & $\$ 1,139,726$ & 4.9 & $\$ 2,250,000$ & 9.7 & $\$ 23,149,726$ \\
\hline 3 & & Rail + Truck & $\$ 10,829,000$ & 74.7 & $\$ 1,424,658$ & 9.8 & $\$ 2,250,000$ & 15.5 & $\$ 14,503,658$ \\
\hline 4 & \multirow{3}{*}{$\mathrm{A} / \mathrm{W}$} & $\begin{array}{c}\text { Truck } \\
\text { (via Mobile) }\end{array}$ & $\$ 9,256,000$ & 67.8 & $\$ 2,136,986$ & 15.7 & $\$ 2,250,000$ & 16.5 & $\$ 13,642,986$ \\
\hline 5 & & $\begin{array}{c}\text { Truck } \\
\text { (via Savannah) }\end{array}$ & $\$ 9,646,000$ & 70.5 & $\$ 1,780,822$ & 13 & $\$ 2,250,000$ & 16.5 & $\$ 13,676,822$ \\
\hline 6 & & Rail + Truck & $\$ 9,919,000$ & 70.7 & $\$ 1,852,055$ & 13.2 & $\$ 2,250,000$ & 16.1 & $\$ 14,021,055$ \\
\hline 7 & Air & Air + Truck & $\$ 53,170,000$ & 95.7 & $\$ 142,466$ & 0.3 & $\$ 2,250,000$ & 4 & $\$ 55,562,466$ \\
\hline
\end{tabular}

\section{Scenario Analysis}

The maritime transport market conditions fluctuate monthly and yearly, depending on the supply and demand of cargo and ships and fluctuations in oil prices, making it doubtful whether the shippers' choice is optimal. Accordingly, all the assumptions made in Section 3 can act as variables, and this study examines whether any changes occur in the optimal mode when the variables change. Additionally, this study selects the optimal transportation route by analyzing the impact of terminal free time in Section 6, which affects the mode selection and total logistics cost.

\subsection{Change in Transportation Cost per Unit from Origin to Destination ( $r$ )}

The cargo volumes and freight rates of the North American line services increase from June to October to secure the products sold during the Thanksgiving and Christmas seasons, depicting the characteristics of the US market. Periodic fare changes during peak seasons relatively make it easy for shippers and logistics service providers to predict and establish countermeasures in advance. However, when unpredictable import and export policies occur, such as the recent trade conflict between the 
USA and China, freight rates largely fluctuate due to changes in volumes to US, making transportation route selection and logistics cost forecasting difficult.

Freight rates take up the largest portion of the total logistics cost in selecting a transportation route and have an important meaning as a variable. The analysis results in Table 7 reveal that the lowest total logistics cost is incurred when using the A/W service with truck transports via the Mobile port, suggesting that it is the most competitive. However, if there is a change in the transportation cost on the competing routes that leads to a change in the total logistics cost, the selection of the optimal route may change. Thus, the transportation cost per unit of the three routes, the truck and rail transport route via the Savannah port and the MLB rail transport route, was adjusted to examine whether the optimal route had changed.

As shown in Figure 2, the transportation cost (r) per unit of truck transportation via the Savannah port was continuously lowered from the existing point, which was $\$ 3710$, to check the point at which the total logistics cost becomes lower than the other routes. The (r) value was found to be $\$ 3696$; if it was lowered by more than $\$ 14$, it could be selected as the optimal transportation route.

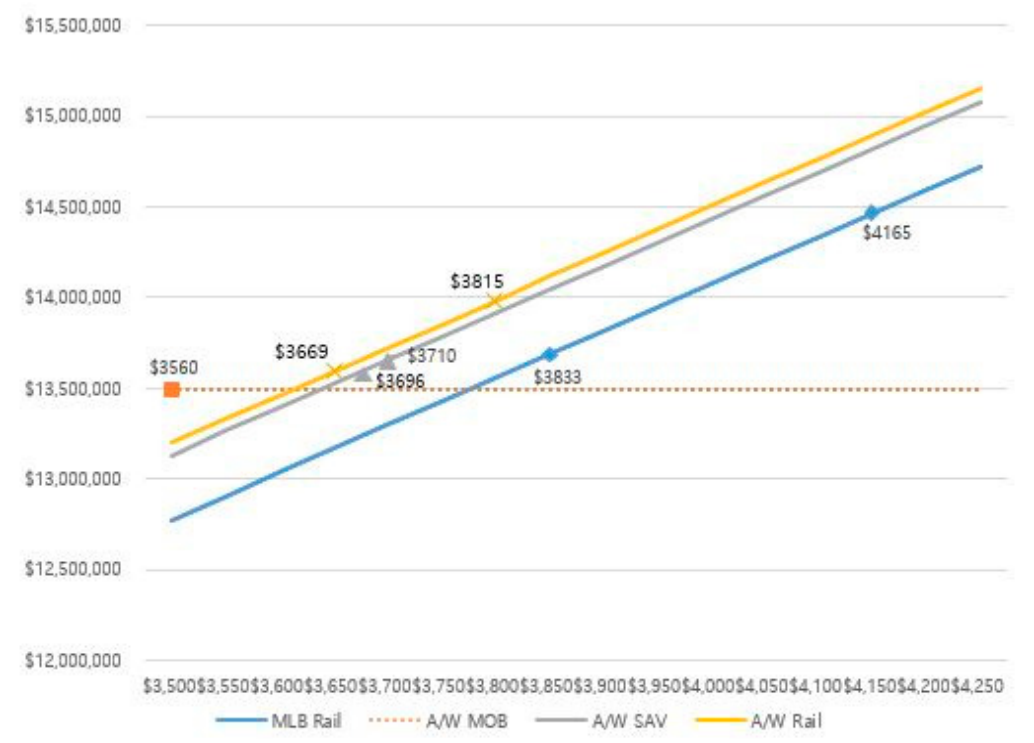

Figure 2. Changes in total logistics costs due to changes in transportation costs per unit.

In the case of rail transportation via the Savannah port, if the transportation cost is reduced by $\$ 146$, from $\$ 3815$ to $\$ 3669$, the total logistics cost would be the lowest, making it the optimal transportation route. The MLB rail transportation used by many shippers had to lower the logistics cost from $\$ 4165$ to $\$ 3833$ to secure competitiveness. Although all three routes with adjusted transportation costs have higher transportation costs from $\$ 109$ to $\$ 273$ than the routes via the Mobile port, the shippers' route selection changes as the total logistics cost decreases. Table 8 presents the change in transportation cost (r) to become the optimal route and following the change in total logistics cost.

Although not shown in Figure 2, team trucks via LA had to lower transport costs to less than $\$ 3998$, which is around half of the existing fare. Single trucks via LA had to lower transport costs to \$3943. Meanwhile, air transport has to lower the cost to less than $\$ 4326$, which is around one fifth of the existing fare, to become competitive in terms of total logistics costs. There is no practical way to lower the transportation cost to this level; hence, it cannot be considered a suitable transportation mode under the conditions assumed in this study. 
Table 8. Analysis of difference in total logistics cost according to transportation cost per unit (r).

\begin{tabular}{cccccc}
\hline No. & & Modes & \multicolumn{2}{c}{ r } & Total Logistics Cost (TC) \\
\hline 1 & A/W & Truck (via Mobile) & \multicolumn{2}{c}{$\$ 3560$} & $\$ 13,642,986$ \\
\hline \multirow{2}{*}{2} & \multirow{2}{*}{ A/W } & \multirow{2}{*}{ Truck (via Savannah) } & Before & $\$ 3710$ & $\$ 13,676,822$ \\
& & After & $\$ 3696$ & $\$ 13,640,422$ \\
\hline \multirow{2}{*}{3} & \multirow{2}{*}{ A/W } & \multirow{2}{*}{ Rail + Truck } & Before & $\$ 3815$ & $\$ 14,021,055$ \\
& \multirow{2}{*}{4} & After & $\$ 3669$ & $\$ 13,641,455$ \\
\hline \multirow{2}{*}{ MLB } & \multirow{2}{*}{ Rail + Truck } & Before & $\$ 4165$ & $\$ 14,503,658$ \\
& & & After & $\$ 3833$ & $\$ 13,640,458$ \\
\hline
\end{tabular}

\subsection{Change in Commodity Value (c)}

Due to the characteristics of automotive parts, there are high-tech parts such as engines and electric parts and low-cost components such as bolt and nuts. Hence, as aforementioned, this study was conducted assuming that the average value of the cargo is $\$ 50,000$ and inventory cost is 0.2. However, when high-priced products, such as automobile high-tech components, semiconductors, displays and advanced materials with short life-cycles are transported, we explore whether truck transportation via the Mobile port is competitive as an optimal transport route, as previously analyzed.

The commodity value was adjusted from $\$ 50,000$ to $\$ 350,000$ in increments of $\$ 25,000$, and the changes in total logistics costs were examined. As shown in Figure 3, when the commodity value is $\$ 50,000$, the truck transport route via the Mobile port had the lowest total logistics cost, which is the most competitive; it showed the steepest increase when the commodity value increased. At the point when the commodity value exceeded $\$ 54,800$, the total logistics cost in the transport route via the Mobile port was higher than that via the Savannah port. From the point where the commodity value exceeded $\$ 116,400$, the truck transport route via the Mobile port's total logistics cost exceeded the other three routes, namely the rail and truck transportation route via the Savannah port and the MLB rail transportation route, resulting in loss of competitiveness as an optimal transportation route.

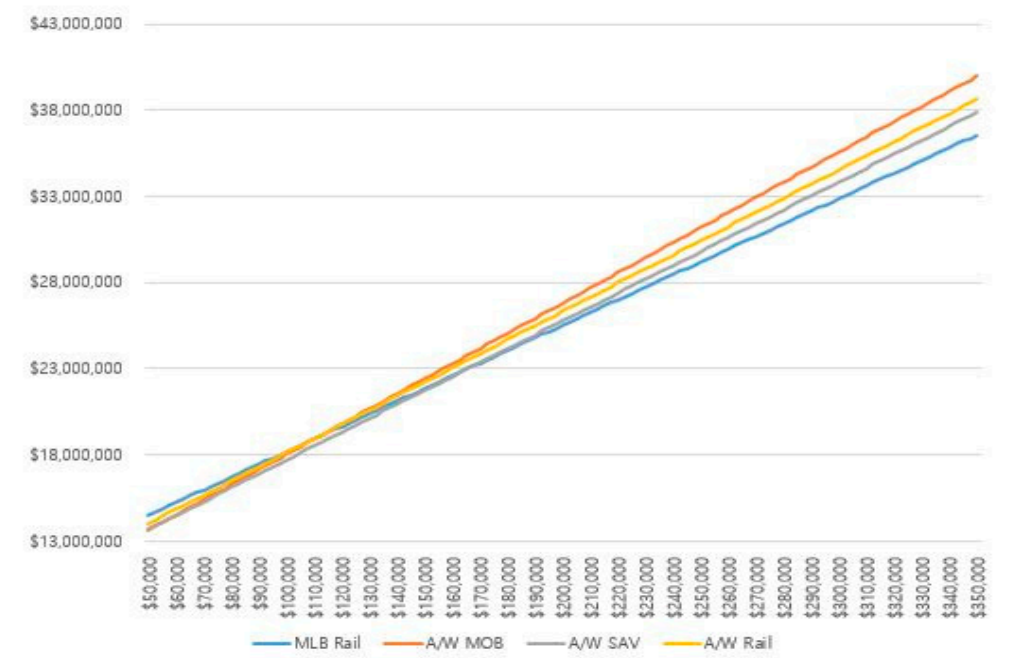

Figure 3. Changes in total logistics costs by changes in commodity value.

On the other hand, MLB rail transportation, which was not competitive due to high transportation cost per unit, showed the lowest sensitivity to increase in commodity value. Moreover, from the point at which the commodity value exceeded $\$ 166,100$, it had the lowest total logistics costs and was regarded as the most competitive route.

For team truck transportation and air transportation, the commodity value should exceed $\$ 1,166,500$ and $\$ 1,893,500$, respectively, to be selected as the optimal transportation mode. However, it 
is not shown in the graph because transporting huge amounts of highly expensive cargo which reaches billions of dollars regularly will not occur realistically.

\subsection{Change in Inventory Cost per Unit (Percentage of Value of Product) (I)}

Next, the inventory cost which was assumed as 0.2 was revised by 0.05 in increments of $25 \%$ to check the changes in total logistics costs. When the inventory cost is 0.2 , the truck route via the Mobile port, which is the most competitive because of the lowest total logistics cost, showed the steepest increase compared with the other three routes as the inventory cost increased. From the point at which the inventory cost exceeded 0.219 , the truck route via the Savannah port became the optimal route. However, when the inventory cost exceeded 0.466 , it lost its competitiveness because of the highest total logistics cost. Figure 4 shows the overall results of change in inventory cost per unit.

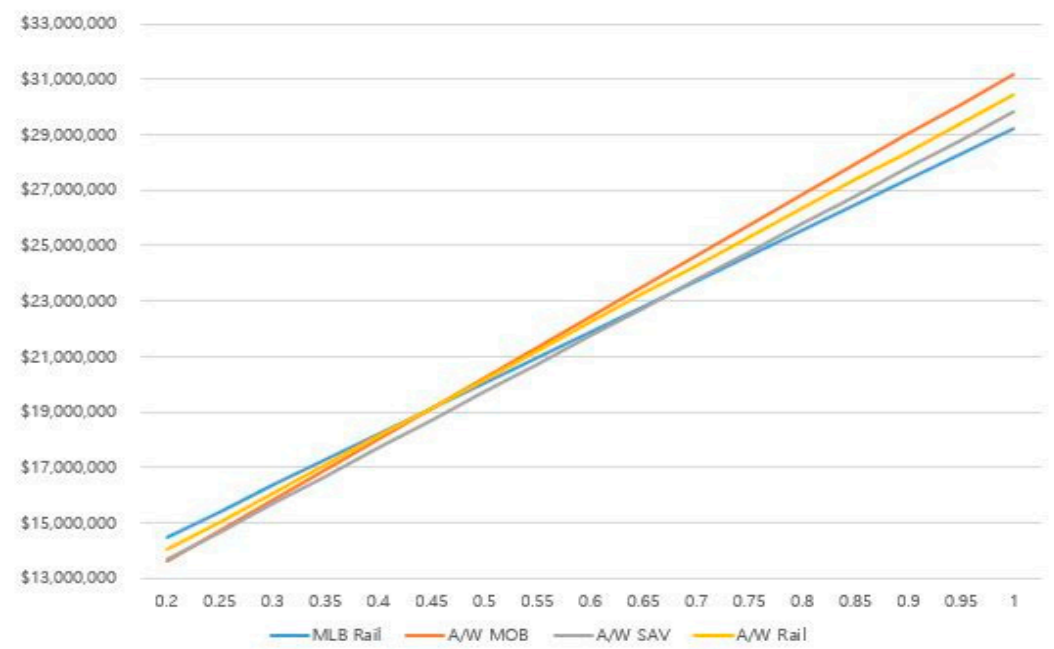

Figure 4. Changes in total logistics costs due to changes in inventory costs per unit.

On the other hand, MLB rail transportation, which was not competitive due to high transportation cost per unit, showed the lowest modest increase, the same trend seen in the change in commodity value (c). From the point at which the inventory cost exceeded 0.665 , the total logistics cost was the lowest among all the competitive route.

The team truck transportation and air transportation were selected as the optimal transportation routes when the inventory cost exceeds 4.666 and 7.574, respectively. Since inventory cost rarely exceeds the commodity value, it is not shown in graph.

Through the analysis under the preconditions assumed in Section 3, we determined that the transportation cost per unit was the most important factor in selecting the transportation route, with the absolute weight placed on the total logistics cost. However, the results of the analysis of the changes in the total logistics cost by adjusting the commodity value and inventory cost reveal that the higher the commodity value and the inventory cost, rather than the lower transportation cost per unit, the shorter the transit time. This could play an important role in the selection of the optimal route or mode for shippers.

\section{Change in Additional Condition}

Besides the conditions mentioned above, one of the important factors that the shippers consider when selecting a transportation route is terminal free time. The storage cost per day at terminals (e.g., ports and railway ramp) is usually very high, around \$100-200 per container. Shippers have to pay a considerable over-storage cost if they exceed the free time provided by logistics companies and terminal operators. Accordingly, many shippers keep containers within the free time, and when the period expires, the container is immediately taken out and moved to the company's warehouse. 
If there is insufficient storage space, containers are moved to a nearby container yard (CY) to store cargoes at a lower cost than in terminals. When this happens, a one-time shuttle cost from the terminal to the adjacent $C Y$ is incurred, which is around $\$ 200-300$, but the storage cost in the CY is much lower, around $\$ 20$ to $\$ 30$ per day, compared with the storage cost at the terminal. Hence, this study additionally investigates whether the optimal transportation route changes by calculating the free time at the destinations' nearby terminals via each transport mode as reduced cost from the total logistics cost.

\subsection{Applying the Terminal Free Time Conditions}

The additional research assumptions are as follows:

1. Shippers fully use the terminal free time and subtract the storage cost in CY by the number of days used in free time.

2. Since containers are stored at a distance at which they can be transported to the final destination on the very day, the number of storage usage days can be replaced for the duration of the period of the terminal free time.

3. The commodity is stored as a substitute for the safety stock of the destination storage; no additional in-transit carrying cost and warehouse inventory cost are incurred.

4. Since the shuttle cost moving to the CY is small and is incurred only once in all modes, it is excluded at the total logistics cost. The yard storage cost is $\$ 20$ per container per day.

The formula applying terminal free time and external CY storage cost, namely the cost of free time, is as follows:

$$
\mathrm{TC}=\mathrm{rD}+\mathrm{ItDC}+\mathrm{S}(\mathrm{D} / \mathrm{Q})+\mathrm{IC}(\mathrm{Q} / 2+4 \mathrm{Q})-\mathrm{fyD}
$$

where $\mathrm{f}$ is the terminal free time and $\mathrm{y}$ is the external CY storage cost (container/day).

Table 9 shows the free time provided by the terminal where the cargo finally passes the transport route on each mode. Among these, the MLB truck (team and single) transportation via LA and the air transportation via Atlanta stress transporting cargos requiring considerable urgency that needs no terminal free time, so it is excluded from the research.

Table 9. Amount of terminal free time by transportation mode.

\begin{tabular}{|c|c|c|c|c|}
\hline No. & & Modes & Destination & Free Time (Day) \\
\hline 1 & \multirow{3}{*}{ MLB } & Truck (Team) & LA & 2 \\
\hline 2 & & Truck (Single) & LA & 2 \\
\hline 3 & & Rail + Truck & Atlanta & 2 \\
\hline 4 & \multirow{3}{*}{$\mathrm{A} / \mathrm{W}$} & Truck & Mobile & 14 \\
\hline 5 & & Truck & Savannah & 14 \\
\hline 6 & & Rail + Truck & Atlanta & 2 \\
\hline 7 & Air & Air + Truck & Atlanta & 2 \\
\hline
\end{tabular}

In the Atlanta rail ramp, only 2 days are provided as free time to all shippers, commonly because space is sparser than in other port terminals. However, in the case of the Mobile or Savannah port terminals, sufficient yards are secured, and 14 days of free time are provided to attract more OCs and shippers. In some cases, to prevent shippers from moving to competing ports and to attract large volumes of cargo, targeting large shippers and logistics companies, 30 days of terminal free time are provided.

Table 10 shows the total logistics cost reflecting the cost of free time depending on the amount of free time. In Atlanta, where the amount of free time is short ( 2 days), the total logistics cost reduction variation was only $0.72 \%$, but the Mobile and Savannah ports that can use 14 days were able to reduce the additional cost by more than $5 \%$ compared to the existing total logistics cost. The $\mathrm{A} / \mathrm{W}$ route via 
the Mobile port without the free time secured around $6 \%$ of logistics cost competitiveness compared to that via the MLB rail route. After the cost of free time is included, the difference in total logistics costs widens by around $10.3 \%$. Thus, the A/W route via the Mobile port is the optimal route, with a competitive logistics cost.

Table 10. Total logistics cost variation when including cost of free time.

\begin{tabular}{|c|c|c|c|c|c|c|c|}
\hline No. & & Modes & $\begin{array}{l}\text { Total } \\
\text { Logistics Cost } \\
\text { (Before) }\end{array}$ & Day & $\begin{array}{l}\text { Cost of } \\
\text { Free Time } \\
\text { (fyD) }\end{array}$ & $\begin{array}{l}\text { Total Logistics } \\
\text { Costs (After) }\end{array}$ & $\begin{array}{l}\text { Variation } \\
(\%)\end{array}$ \\
\hline 1 & MLB & Rail + Truck & $\$ 14,503,658$ & 2 & $\$ 104,000$ & $\$ 14,399,658$ & $-0.72 \%$ \\
\hline 2 & \multirow{3}{*}{$\mathrm{A} / \mathrm{W}$} & Truck (via Mobile) & $\$ 13,642,986$ & 14 & $\$ 728,000$ & $\$ 12,914,986$ & $-5.34 \%$ \\
\hline 3 & & $\begin{array}{l}\text { Truck (via } \\
\text { Savannah) }\end{array}$ & $\$ 13,676,822$ & 14 & $\$ 728,000$ & $\$ 12,948,822$ & $-5.32 \%$ \\
\hline 4 & & Rail + Truck & $\$ 14,021,055$ & 2 & $\$ 104,000$ & $\$ 13,917,055$ & $-0.74 \%$ \\
\hline
\end{tabular}

\subsection{Change in Terminal Free Time}

In the Southeastern USA, apart from the Savannah and Mobile ports, there are other ports, such as Charleston and Jacksonville. Each port provides a separate terminal free time for large shippers and logistics companies in order to attract large volumes of cargoes and secure competitiveness. Assuming such a case, a scenario analysis was conducted to determine how many additional free time ports and railway ramps are provided by other ports to compete with the Mobile port and secure competitiveness. Here, it is premised that the terminal free time at the Mobile port is 14 days, as before. Figure 5 shows the change in total logistics cost when extra free time is provided in addition to the terminal free time basically provided by each terminal on each route.

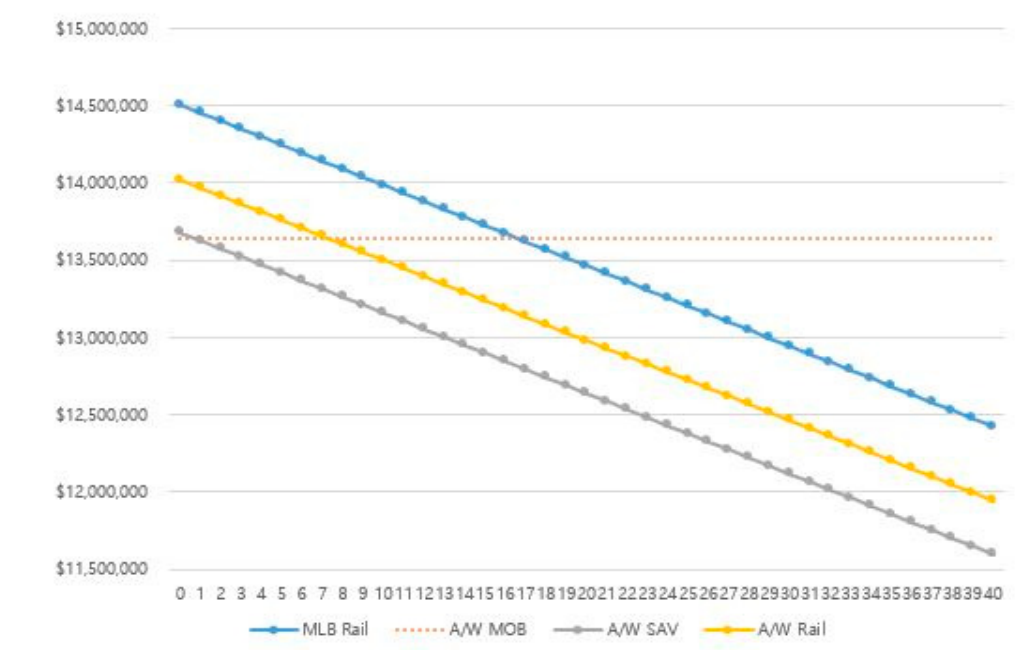

Figure 5. Change in total logistics costs by providing additional free time.

In the case of the truck transportation route via the Mobile port, which was provided with 14 days of terminal free time, the total logistics cost was $\$ 12,914,986$. The truck transportation route via the Savannah port was also provided with the same terminal free time of 14 days, but the total logistics cost was $\$ 12,948,822$, which is $\$ 33,836$ more than the Mobile port, implying a lack of competitiveness. However, when the free time at the Savannah port reaches only one extra day, $\$ 52,000$ of storage cost is reduced and the total logistics cost is lowered to $\$ 12,896,822$, thereby securing competitiveness over the route via the Mobile port.

Rail transportation routes via the Savannah port will also be cost-competitive compared to truck transportation via the Mobile Port if 20 days of extra free time are provided in addition to the basic two-day free time. When an additional 29 days of free time are provided in addition to the basic free 
time, the MLB rail transport route can also attract shippers as the total logistics cost will be lower than that of trucking via the Mobile port.

Lastly, considering the fact that each terminal currently has a different amount of free time depending on the shipper, the terminal free time provided by the Savannah port and Atlanta railway has been changed. Consequently, if only one day of extra free time is secured compared to the previous, Savannah port can be more competitive than the Mobile port in terms of total logistics cost. A total of 22 days of free time for A/W rail transport and 31 days for MLB rail transport were additionally required.

\section{Conclusions}

As a result of globalization, selecting efficient transportation routes and mode is important. Thus, based on the theoretical consideration of the intermodal transportation route selection and literature review on the factors of transport routes selection, seven transport routes and modes to Montgomery, USA, were analyzed. The transportation route with the lowest total logistics costs, including transportation costs, in-transit carrying costs and warehouse inventory costs, was considered as the optimal route. To this end, company A's actual logistics status and the logistics market fare of Q3 of 2019 were employed for the analysis.

The findings in company A's automotive parts export case from Korea to Montgomery, USA, show that using $\mathrm{A} / \mathrm{W}$ truck transportation via the Mobile port was approximately $0.25 \%$ more competitive than that via the Savannah port in terms of total logistics cost. The total logistics cost was competitive by around $3 \%$ and $6 \%$ compared to the $\mathrm{A} / \mathrm{W}$ rail transportation and MLB rail transportation services, respectively.

The results of the scenario analysis through modifying the parameters of variable values, such as transportation cost, commodity value and inventory cost, revealed that high-priced products and inventory costs responded sensitively to transit times; MLB rail transportation, team trucks and air transportation, which were not economical before, became relatively competitive. After applying the terminal free time conditions, using the Mobile and Savannah ports that provide a relatively large amount of free time further reduces the total logistics cost by more than $5 \%$, through reducing the storage cost.

Based on the analysis, in deriving the total logistics cost, the variability of transportation cost, in-transit carrying cost and inventory cost should be considered. Moreover, the optimal transportation route should be selected by taking into account the additional conditions provided by the OC and the terminal in the logistics cost. Not only the shippers but also terminal operators, shipping companies, and logistics companies will be helpful in attracting volumes by utilizing competitive transportation routes based on the analyzed data.

This study makes significant contributions to both theory and practice. With respect to the theoretical implication, the present research enriches the literature by applying an inventory-theoretic model adapted from air transportation which is important in automotive parts logistics in order to suggest the most efficient transportation route by comparing the transportation routes and modes from Korea to the US. By applying this model, warehouse inventory cost and in-transit carrying cost, part of the inventory cost, could be considered. In addition, through the inventory-theoretic model, it was possible to take into account not only the shipper's point of view also the perspective of other logistics service providers that offer intermodal transportation [14].

Another contribution of this research is applying real data formed in the shipping market to analyze changes after the expansion of the Panama Canal. In the study of Woo et al. [4], the analysis used data from 2013 to 2014, before the expansion of the Panama Canal, and showed that the Savannah route was selected as the most optimal route, but the Mobile route was the least expensive in this study. It may seem that the destination has been changed from the Luverne to the Montgomery, which is around a 51-mile distance in the same state. This means that the optimal transportation route could change even if the final destination is slightly varied. Regarding the transit time, it took 36.9 days via Savannah and 46.74 days via Mobile. However, after the Panama Canal expanded, it was verified that 
the transit time had reduced to 25 and 30 days, respectively. In the case of rail transportation via the $\mathrm{A} / \mathrm{W}$ route, it was not competitive in all aspects, such as cost, transit time and free time, compared to the truck transportation service. However, for companies located near railroad ramps, rail transport services may be sufficiently economical.

The last noteworthy implication of this paper is that it accounts for the terminal free time, which is an implicit cost. This study investigated whether the optimal transportation route changes by calculating the terminal free time via each transport mode as reduced cost from the total logistics cost. Overall, shippers have to pay a considerable over-storage cost if they exceed the free time offered by logistics companies and terminal operators. Due to this cost, many shippers keep containers within the free time, and when the period expires, the container is immediately taken out and moved to the company's warehouse. Hence, this study incorporated terminal free time in their analysis, which is a key contribution to the literature. However, the MLB truck (team and single) transportation via LA and the air transportation via Atlanta were ignored, since they were mainly used for transporting cargos requiring considerable urgency that need no terminal free time.

This study provides important managerial implications for Korean logistics companies and shippers regarding the route selection by comparing the seven routes. In comparison with maritime transportation, using air transport has an advantage in terms of transit time, which can be reduced by around 12 28 days. The results of this study suggest that air transport has to cost around one-fifth of the existing fare to become competitive. From the viewpoint of the total logistics costs, this means that if the lead time is not met, an additional cost of $\$ 41,919,479$, which is approximately 4.07 times compared with that of the $\mathrm{A} / \mathrm{W}$ route via the Mobile port, is required in order to meet the actual delivery date. Therefore, meeting the lead time and delivery order scenario is one of the approaches to reducing total logistics costs. From a positive point of view, lead time and delivery order can be managed by proper supply chain management. Truck and rail route via Savannah port and MLB rail transportation service providers need to develop plans to reduce the total logistics costs, such as extending the free time, reducing direct shipping costs or reducing in-transit carrying costs to attract cargoes. In addition, since the Mobile port lost its competitiveness when the Savannah port offers only one extra day of free time, a scheme to reduce total logistics costs has to be implemented in order to retain competitiveness.

Rail ramp service operators should concentrate on drawing up a plan to attract volumes that directly affect sales. The findings of the study show that an additional total of 22 days of free time for $\mathrm{A} / \mathrm{W}$ rail transport and 31 days for MLB rail transport were required. However, realistically, it is impossible to provide these in rail transportation. Nonetheless, if extended free time is provided at a low cost through a strategic alliance with many off-dock container yards (ODCY) near the terminal, sufficient competitiveness will be secured in order to replace the competitive line. Thus, rail ramp service operators may attract large volumes of cargo. Moreover, in places where congestion occurs frequently such as LA, there may be an over-storage cost owing to the bottleneck, which can be reduced through a strategic alliance with ODCY.

Lastly, through the scenario analysis, we found that optimal transportation routes can be altered when the values of the variables change. Consequently, decision-makers should recognize that total logistics costs may vary when commodity value (C), inventory costs (I), transportation costs ( $\mathrm{r}$ ) and terminal free time change. In addition, concerning the shuttle service, both truck transportation in port and railway ramps can be reached within a day. However, in the actual transportation from railroad ramps, a shuttle service is possible at a short distance. Therefore, the shipper's satisfaction can be increased by shortening the transit time even by a few hours.

As for the research limitations, the inventory cost (I) in the inventory-theoretic model was calculated to be $0.2,10 \%$ of the commodity price and with a $10 \%$ interest rate on the annual shipment value, because of the characteristics of automobile parts. This is considered an important variable in which the total logistics cost increases significantly even when the inventory cost increases by a little. Hence, accurate research on inventory costs is required. Moreover, the level of transportation 
service is important in terms of non-transportation cost in selecting a transportation route. Future research should consider service factors such as lead time irregularities due to frequent rail connection delays at the MLB rail route via the LA port and document closing and cargo closing, etc., with cost factors. Lastly, although it was not used by company A, the sea-air intermodal transportation route via Vancouver could be reflected in future research.

Author Contributions: Conceptualization, K.-S.P.; methodology, J.K., K.K.; formal analysis, J.K., K.K.; investigation, K.K.; writing—original draft preparation, J.K., K.K.; writing—review and editing, K.F.Y., K.-S.K. All authors have read and agreed to the published version of the manuscript.

Funding: This research received no external funding.

Conflicts of Interest: The authors declare no conflict of interest.

\section{References}

1. Korea International Trade Association. Trade Statistical Data. Available online: http://stat.kita.net/stat/istat/ uts/UsCtrImpExpList.screen (accessed on 22 March 2020).

2. Pierreval, H.; Bruniaux, R.; Caux, C. A continuous simulation approach for supply chains in the automotive industry. Simul. Model. Pract. Theory 2007, 15, 185-198. [CrossRef]

3. Korea Customs Service. Top 10 Import and Export Items. Available online: http://www.index.go.kr/potal/ main/EachDtlPageDetail.do?idx_cd=2455 (accessed on 22 March 2020).

4. Woo, S.H.; Kim, S.N.; Kwak, D.W.; Pettit, S.; Beresford, A. Multimodal route choice in maritime transportation: The case of Korean auto-parts exporters. Marit. Policy Manag. 2018, 45, 19-33. [CrossRef]

5. Moon, D.S.; Kim, D.J.; Lee, E.K. A study on competitiveness of sea transport by comparing international transport routes between Korea and EU. Asian J. Shipp. Logist. 2015, 31, 1-20. [CrossRef]

6. Pham, T.Y.; Kim, K.Y.; Yeo, G.T. The Panama Canal expansion and its impact on east-west liner shipping route selection. Sustainability 2018, 10, 4353. [CrossRef]

7. Ayar, B.; Yaman, H. An intermodal multicommodity routing problem with scheduled services. Comput. Optim. Appl. 2012, 53, 131-153. [CrossRef]

8. Gallo, A.; Accorsi, R.; Baruffaldi, G.; Manzini, R. Designing sustainable cold chains for long-range food distribution: Energy-effective corridors on the Silk Road Belt. Sustainability 2017, 9, 2044. [CrossRef]

9. Daham, H.A.; Yang, X.; Warnes, M.K. An efficient mixed integer programming model for pairing containers in inland transportation based on the assignment of orders. J. Oper. Res. Soc. 2017, 68, 678-694. [CrossRef]

10. Xing, J.; Zhong, M. A reactive container rerouting model for container flow recovery in a hub-and-spoke liner shipping network. Marit. Policy Manag. 2017, 44, 744-760. [CrossRef]

11. Huang, K.; Lee, Y.T.; Xu, H. A routing and consolidation decision model for containerized air-land intermodal operations. Comput. Ind. Eng. 2020, 141, 106299. [CrossRef]

12. Tian, W.; Cao, C. A generalized interval fuzzy mixed integer programming model for a multimodal transportation problem under uncertainty. Eng. Optim. 2017, 49, 481-498. [CrossRef]

13. Hao, C.; Yue, Y. Optimization on Combination of Transport Routes and Modes on Dynamic Programming for a Container Multimodal Transport System. Procedia Eng. 2016, 137, 382-390. [CrossRef]

14. Wang, Y.; Yeo, G.T. Intermodal route selection for cargo transportation from Korea to Central Asia by adopting Fuzzy Delphi and Fuzzy ELECTRE I methods. Marit. Policy Manag. 2018, 45, 3-18. [CrossRef]

15. Pham, T.Y.; Yeo, G.T. A comparative analysis selecting the transport routes of electronics components from China to Vietnam. Sustainability 2018, 10, 2444. [CrossRef]

16. Beresford, A.K. Modelling freight transport costs: A case study of the UK-Greece corridor. Int. J. Logist. Res. Appl. 1999, 2, 229-246. [CrossRef]

17. Banomyong, R.; Beresford, A.K. Multimodal transport: The case of Laotian garment exporters. Int. J. Phys. Distrib. Logist. Manag. 2001, 31, 663-685. [CrossRef]

18. Beresford, A.; Pettit, S.; Liu, Y. Multimodal supply chains: Iron ore from Australia to China. Supply Chain Manag. Int. J. 2011, 16, 32-42. [CrossRef]

19. Seo, Y.J.; Chen, F.; Roh, S.Y. Multimodal transportation: The case of laptop from Chongqing in China to Rotterdam in Europe. Asian J. Shipp. Logist. 2017, 33, 155-165. [CrossRef] 
20. Banomyong, R. Assessing import channels for a land-locked country: The case of Lao PDR. Asia Pac. J. Mark. Logist. 2004, 16, 62-81. [CrossRef]

21. Regmi, M.B.; Hanaoka, S. Assessment of intermodal transport corridors: Cases from North-East and Central Asia. Res. Transp. Bus. Manag. 2012, 5, 27-37. [CrossRef]

22. Collison, F.M. Market segments for marine liner service. Transp. J. 1984, 24, 40-54.

23. McGinnis, M.A. A comparative evaluation of freight transportation choice models. Transp. J. 1989, $29,36-46$.

24. Kim, G.S.; Lee, S.W.; Seo, Y.J.; Kim, A.R. Multimodal transportation via TSR for effective Northern logistics. Marit. Bus. Rev. 2020. [CrossRef]

25. Cunningham, W.H. Freight modal choice and competition in transportation: A critique and categorization of analysis techniques. Transp. J. 1982, 21, 66-75.

26. Liu, M.; Kronbak, J. The potential economic viability of using the Northern Sea Route (NSR) as an alternative route between Asia and Europe. J. Transp. Geogr. 2010, 18, 434-444. [CrossRef]

27. Shibasaki, R.; Azuma, T.; Yoshida, T.; Teranishi, H.; Abe, M. Global route choice and its modelling of dry bulk carriers based on vessel movement database: Focusing on the Suez Canal. Res. Transp. Bus. Manag. 2017, 25, 51-65. [CrossRef]

28. Wang, S.; Yang, D.; Lu, J. A connectivity reliability-cost approach for path selection in the maritime transportation of China's crude oil imports. Marit. Policy Manag. 2018, 45, 567-584. [CrossRef]

29. Verny, J.; Grigentin, C. Container shipping on the northern sea route. Int. J. Prod. Econ. 2009, 122, 107-117. [CrossRef]

30. Zeng, Q.; Lu, T.; Lin, K.C.; Yuen, K.F.; Li, K.X. The competitiveness of Arctic shipping over Suez Canal and China-Europe railway. Transp. Policy 2020, 86, 34-43. [CrossRef]

31. Salin, D.L. Impact of Panama Canal Expansion on the US Intermodal System. United States Department of Agriculture. Agricultural Marketing Service, Transportation and Marketing Program 2010. Available online: https://ageconsearch.umn.edu/record/147032 (accessed on 18 February 2020).

32. Martinez, C.; Steven, A.B.; Dresner, M. East Coast vs. West Coast: The impact of the Panama Canal's expansion on the routing of Asian imports into the United States. Transp. Res. Part E Logist. Transp. Rev. 2016, 91, 274-289. [CrossRef]

33. Ungo, R.; Sabonge, R. A competitive analysis of Panama Canal routes. Marit. Policy Manag. 2012, 39, 555-570. [CrossRef]

34. Van Hassel, E.; Meersman, H.; Van de Voorde, E.; Vanelslander, T. The impact of the expanded Panama Canal on port range choice for cargo flows from the US to Europe. Marit. Policy Manag. 2020. [CrossRef]

35. Moryadee, S.; Gabriel, S.A. Panama Canal Expansion: Will Panama Canal Be a Game-Changer for Liquefied Natural Gas Exports to Asia? J. Energy Eng. 2017, 143, 04016024. [CrossRef]

36. Liu, Q.; Wilson, W.W.; Luo, M. The impact of Panama Canal expansion on the container-shipping market: A cooperative game theory approach. Marit. Policy Manag. 2016, 43, 209-221. [CrossRef]

37. Corbett, J.J.; Deans, E.; Silberman, J.; Morehouse, E.; Craft, E.; Norsworthy, M. Panama Canal expansion: Emission changes from possible US west coast modal shift. Carbon Manag. 2012, 3, 569-588. [CrossRef]

38. De Marucci, S. The expansion of the Panama Canal and its impact on global $\mathrm{CO}_{2}$ emissions from ships. Marit. Policy Manag. 2012, 39, 603-620. [CrossRef]

39. Carral, L.; Fernández-Garrido, C.; Vega, A.; Sabonge, R. Importance of the Panama Canal in the reduction of CO2 emissions from maritime transport. Int. J. Sustain. Transp. 2019, 1-14. [CrossRef]

40. Baumol, W.J.; Vinod, H.D. An inventory theoretic model of freight transport demand. Manag. Sci. 1970, 16, 413-421. [CrossRef]

41. Offshore Energy. Maersk Line Hints at Increasing Use of New Panama Canal. Available online: https://www. offshore-energy.biz/maersk-line-hints-at-increasing-use-of-new-panama-canal/ (accessed on 22 March 2020).

42. Yonhap News. Asia-US East Coast Container Ships, Changing Route from Suez to Panama Canal. Available online: https://www.yna.co.kr/view/AKR20160718095200076 (accessed on 22 March 2020).

(C) 2020 by the authors. Licensee MDPI, Basel, Switzerland. This article is an open access article distributed under the terms and conditions of the Creative Commons Attribution (CC BY) license (http://creativecommons.org/licenses/by/4.0/). 